\title{
Alternative Transportation Expenditures In Development Strategy: Arterial Highways Versus Local Roads\#
}

\author{
F. Thomas Ayers, JR. And Lewis Freiberg, JR.*
}

\section{Introduction}

The effect of transportation upon land values has long been a subject of interest to economists and regional planners. One particular area of interest, exemplified by the work of Haig, Alonso, Wingo, and Goldberg, centers around aggregate urban rents, land use, and urban form, the major emphasis being on the effects of new transportation networks upon metropolitan areas and their suburbs.

This work, however, also bears directly upon the economic development of rural areas. To generally summarize the aspect of Haig's theory relevant to this study, economic units in determining the location of their activities seek to minimize the sum of site rental and transportation costs. For metropolitan areas a general improvement in transportation will lower transportation cost and allow firms and households to move from the economic center of the area, where site rents are relatively high, to the periphery, where site rents are lower. This shifting of the demand for sites to outlying rural areas, will cause site rents (hence, land values) to increase in these areas relative to the economic center. The increasing site rents reflect the increased economic potential of land at the periphery resulting from the lower costs of transportation.

The implication of this theory is that while some economic activity will be relocated (and new activity located) at the periphery, the extent of the relocation will be limited by the nature of the transportation costs as one moves further from the center and by increasing site rents as the demand for sites at the periphery is increased. Hence, this theory has direct bearing upon the effects of transportation upon economic development.

As Wilson has pointed out, the idea that transportation facilitates economic activity is an old concept. In his seminal work, Hirschman has suggested that improvement in the infrastructure of a region (including highways ) may increase the rate of economic growth. This idea of infrastructure improvement leading economic development has found its

\#Research for this paper was sponsored by the Institute for Real Estate and Land Use Analysis, University of Kentucky.

*The authors are, respectively, Director of Economic Research, The Onyx Corporation and Research Economist Blue Shield Association. This research was undertaken while both were Assistant Professors of Economics, Morehead State University. 
way into economic policy with the Appalachian Redevelopment Act of 1964. One feature of this act-the Development Highway System-is directly based upon this notion.

Considerable controversy has arisen however over the effectiveness of highways in generating economic development. The point of controversy centers not on whether or not highways affect growth, but on the magnitude of the effect and whether or not growth might be better promoted by other types of expenditures. For example, both Wright and Blase, and Kuhn and West find that arterial highways have only a modest effect upon economic development and suggest that the effects soon exhaust themselves. Hansen and Munro each suggest that expenditures should be shifted from arterial highways to other forms of social overhead capital. While Hale and Walters support the Development Highway System, they see its effects not as promoting economic development of the region but as promoting out-migration and economic development in the peripheral urban centers of the region. Indeed it has been suggested by Bowman and Haynes that improved transportation networks may even hurt some localities by opening their local service industries to competition.

This paper examines the impact of Interstate 64 (I-64) on land values in five rural but diverse counties in Eastern Kentucky. Since the corridor of I-64 examined is bounded on the West by Lexington, Kentucky and on the East by Ashland, Kentucky and Huntington, West Virginia, it is possible to test Haig's theory of location and the extent to which I-64 has promoted economic development within the corridor.

\section{Data and Model}

Time series data for a ten year period were collected and analyzed on a monthly basis for each county within the corridor. The general socioeconomic data were obtained from the Division of Research and Planning, Kentucky Department of Commerce. The interstate announcement and construction data were obtained from the Kentucky Department of Transportation. The data relating to land transactions is primary data gathered from the individual county courthouses. All land transactions within the ten year period (excluding intrafamily transactions and transactions conveying less than full interest in the property transferred) were collected and a twenty per cent random sample was selected for each county. Each observation was located on a county map so that the appropriate distance variables could be determined.

Multiple regression analysis was then used to test the impact model. The model is,

$$
\mathrm{Y}=\mathrm{a}_{\mathbf{0}}+\sum_{\mathrm{i}=1}^{11} \mathrm{~b}_{\mathrm{i}} \mathrm{X}_{\mathrm{i}}+\mathrm{u}
$$


where,
$\mathrm{Y}=$ price per acre
$\mathrm{X}_{1}=$ total county population
$\mathrm{X}_{2}=$ interest rate
$\mathrm{X}_{3}=$ per capita income
$\mathrm{X}_{4}=$ number of acres in transaction
$\mathrm{X}_{5}=$ distance to nearest economic center
$\mathrm{X}_{6}=$ distance to $\mathrm{I}-64$
$\mathrm{X}_{7}=$ number of months since corridor announcement
$\mathrm{X}_{8}=$ number of months since corridor completion
$\mathrm{X}_{9}=$ dummy variables "at interchange"
$\mathrm{X}_{10}=$ dummy variable: "continguous to I-64 but not at inter- change"
$\mathrm{X}_{11}=$ dummy variable: "building on land"

The dummy variable indicating the existence of buildings on the land, $\mathrm{X}_{11}$, was included to absorb the influence of buildings on transaction price. This was necessary since the deeds of conveyence indicated only the presence of, and not the size or condition of, buildings.

County population, $\mathrm{X}_{1}$, and per capita income, $\mathrm{X}_{3}$, are expected to be directly related to price per acre, while interest rates, $X_{2}$, and the number of acres in transaction, $\mathrm{X}_{4}$, are expected to be inversely related to price per acre. The $a$ priori sign for $\mathrm{X}_{4}$ is negative because it is expected that certain economies of scale exist in land purchases. For example, certain costs such as legal fees and title searches tend to be relatively fixed. Additionally, land of high economic potential, for example industrial sites, tends to sell in smaller allotments than land of lower economic potential (general farm land).

The distance to the nearest economic center, $\mathrm{X}_{5}$, is particularly important because the further removed a site is from the economic center of the area, in this case county seats, the lower the site rent and the higher the transportation cost. Hence, the a priori sign of this variable is negative. ${ }^{1}$ To test the adequacy of a twenty percent sample, a forty percent sample was also analyzed for Rowan County. Using the Chow Test, it was determined at the 95 percent level of confidence that there was no significant difference between the results of the twenty and forty percent samples.

The remaining variables, $\mathrm{X}_{6}-\mathrm{X}_{10}$, are designed to show the impact of I-64 upon land values. The variables $\mathrm{X}_{7}$ and $\mathrm{X}_{8}$ were included to show any announcement and completion effects of I-64 within the counties. The ten year analysis period was selected in an attempt to span both dates. The a priori sign for both $\mathrm{X}_{7}$ and $\mathrm{X}_{8}$ is positive.

The variables, "distance to I-64," $\mathrm{X}_{6}$; "transaction at the interchange", $\mathrm{X}_{9}$; and "transaction contiguous to I-64 but not at interchange", $\mathrm{X}_{10}$, were included to reflect accessibility and proximity effects. The $a$ priori 
sign for $\mathrm{X}_{9}$, since it indicates land on I-64 interchanges is positive. It is known that in some instances the interstate bisected agricultural production units such as dairy farms. In these instances the costs of production were increased (because traversing the interstate now requires the increased transportation cost of going to interchanges). In order to determine whether or not such effects were significant in the aggregate, $\mathrm{X}_{10}$ was included in the model and its a priori sign is negative.

Finally, the a priori sign of "distance to I- 64 ," $\mathrm{X}_{6}$, may be positive or negative depending upon the relative strength of the accessibility and proximity effects. If the interstate is to exert a positive influence upon economic development the sign should be negative indicating that accessibility to the interstate enhances the economic potential of the site.

\section{Empirical Results}

Regression equations were run for each county and for the five county area. The results are presented in the following table.

As expected, the presence of building, $\mathrm{X}_{11}$, was the most important variable in each county equation as well as the area equation. Having accounted for this effect, interesting results are obtained for distance to economic center, $\mathrm{X}_{5}$, and the interstate variables, $\mathrm{X}_{6}$ through $\mathrm{X}_{10}$, which suggest specific development strategies for planners.

First, distance to I-64, $\mathrm{X}_{6}$, enters the equations only in Clark County, which is contiguous to the Lexington Metropolitan area, and in Carter County, which is contiguous to the Ashland-Huntington metropolitan area. These positive accessibility effects indicate strong intercounty linkages which exist between these counties and the metropolitan areas. It is also interesting that in these counties distance to the nearest intracounty economic center does not enter the equations as a significant variable. Additionally the interchange variable, $\mathrm{X}_{9}$, also appears significant in both counties; although in Clark it has the wrong sign. This initially puzzling result, however, can be explained by considering development in Clark. The development of subdivisions with access to the interchange, but not actually within the interchange, has proceeded at such a rapid rate that these transactions, with houses included, have resulted in a high price per acre when compared to the interchange transactions. Hence, the interchange dummy applied to undeveloped land results in a negative sign.

Rowan County was the only other county wherein $\mathrm{X}_{9}$ proved significant. Since Rowan County is the midpoint between the two metropolitan areas, it is not an illogical point for interchange development by industrial concerns (e.g., oil and coal companies, regional shopping areas, etc.).

The only other county where interstate variables were significant was Bath County where $\mathrm{X}_{7}$, the announcement effect, appears to have had moderate influence. Aside from $\mathrm{X}_{11}$, the most significant variable in the three interior counties-Montgomery, Bath, and Rowan-was the distance to the intracounty economic center, $\mathrm{X}_{5}$. Within these counties the 
TABLE: COUNTY AND TOTAL REGRESSION EQUATIONS

\begin{tabular}{|c|c|c|c|c|}
\hline Area & Equation & $\mathbf{R}^{2}$ & $\begin{array}{c}\text { Durbin- } \\
\text { Watson } \\
\text { Test }\end{array}$ & $\begin{array}{c}\text { Kolmogorov- } \\
\text { Smirnov } \\
\text { Test }\end{array}$ \\
\hline \multirow[t]{2}{*}{$\begin{array}{l}\text { Clark County } \\
940 \text { Observations }\end{array}$} & 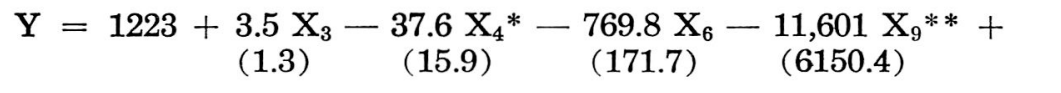 & .4162 & 1.95 & .18 \\
\hline & $\begin{array}{l}29,238 \mathrm{X}_{11} \\
(1328.9)\end{array}$ & & & \\
\hline $\begin{array}{l}\text { Montgomery County } \\
613 \text { Observations }\end{array}$ & $\mathrm{Y}=22,964.6-\underset{(610.1)}{3012.9} \mathrm{X}_{5}+\underset{(4958.5)}{32,516.2} \mathrm{X}_{11}$ & .1421 & 2.04 & .35 \\
\hline $\begin{array}{l}\text { Bath County } \\
296 \text { Observations }\end{array}$ & 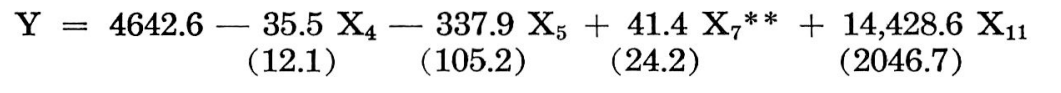 & .2486 & 1.79 & .29 \\
\hline $\begin{array}{l}\text { Rowan County } \\
430 \text { Observations }\end{array}$ & $\mathrm{Y}=4971.5+\underset{(.03)}{.25} \mathrm{X}_{1}-\underset{(203)}{1077} \mathrm{X}_{5}+\underset{(3396.2)}{5529.5 \mathrm{X}_{9} * *}+\underset{(1310.6)}{26,449.1 \mathrm{X}_{11}}$ & .5534 & 1.82 & .26 \\
\hline $\begin{array}{l}\text { Carter County } \\
752 \text { Observations }\end{array}$ & $\mathrm{Y}=3287.3-\underset{(201)}{1125.1} \mathrm{X}_{6}+\underset{(22.3)}{117.6} \mathrm{X}_{8}+\underset{(1835.1)}{3578 \mathrm{X}_{9} *}+\underset{(953.3)}{16,323.6} \mathrm{X}_{11}$ & .3505 & 2.00 & .29 \\
\hline \multirow[t]{2}{*}{ Five-County Area } & 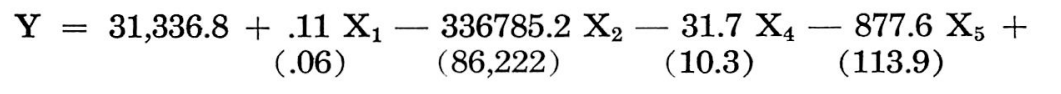 & .2405 & 1.93 & .25 \\
\hline & $\begin{array}{l}182 \mathrm{X}_{8}+\underset{(1018.1)}{246.6)} \\
\left(24.596 \mathrm{X}_{11}\right.\end{array}$ & & & \\
\hline
\end{tabular}

*Significant at .05

**Significant at .1

All others significant at .01 
interstate appears to have had little effect upon land values within the time period under consideration.

Furthermore, the interstate is not expected to affect transportation costs to these local economic centers because in intracounty travel the interstate cannot be used. For example, in every county interchanges are located only near the economic centers so that travel from the outlying areas of the county to the economic center must be done on secondary roads. Interstates, on the other hand, provide only a linkage for the counties with other counties and with the more distant larger urban areas-in this case Lexington and Ashland-Huntington. In examining the influence of these variables, the importance of the intracounty and intercounty linkage effects can be determined. Clearly, a strategy of development emphasizing arterial highways requires strong intercounty linkages while a strategy emphasizing the development of local transportation requires strong intracounty linkages.

The significance of $\mathrm{X}_{5}$ in the three interior county equations and the absence of the interstate variables for these counties' equations suggest that intracounty linkages are most important in these counties. Hence, a strategy of the development of local roads would lower transportation cost to the intracounty center and thereby increase the economic potential of the land at the periphery. In the counties contiguous to urban areas the interstate highway has had a direct and substantial impact, suggesting a strategy of arterial highways linking these counties with the urban centers.

This is not to suggest that arterial highways do not influence development in the center counties in the long run. As land values near the urban center increase because of increased economic activity, the presence of arterial highways allows growth to proceed along the corridor as economic units adjust location in response to increasing site rents. With this type of strategy, however, the impetus for development, while it may eventually reach distant rural areas, comes from growth in the already developed urban centers rather than from development within the rural areas. Hence, the time lags between construction of the interstates and development in the rural counties depends upon the vitality of the urban area and is likely to be quite long. A strategy of local road development, however, would be directed toward intracounty linkages and increasing the economic vitality of the rural areas themselves. Internal, versus external, development would likely be subject to a shorter lag between construction and economic impact.

The variable $\mathrm{X}_{4}$ appears as a significant variable in the Clark, Bath, and aggregate equations. In all equations $\mathrm{X}_{4}$ has the appropriate sign and indicates that the larger the number of acres in the transactions the lower is the price per acre. As previously suggested, this likely results from certain purchase costs which are fixed, land with relatively high economic potential selling in smaller portions, and the increased bargaining power of large land purchasers. 
When the county data were combined the influence of I-64 variables is reduced. In the aggregate, $\mathrm{X}_{5}$ appears to be the major influential variable. The only interstate variable of consequence is $\mathrm{X}_{8}$.

\section{Conclusions}

The fundamental implication of our analysis is that arterial highways may well be necessary, but are far from a sufficient, generator of economic development. The economic impact of an arterial highway is unequally distributed along its length with the impact being greatest at the urban periphery. Rural areas are not as directly affected by massive spending on arterial highways as conventional wisdom suggests.

Since it is generally the rural areas (e.g., Appalachia) that are in the greatest need of economic development, alternative approaches to development might be considered. This study indicates that one candidate for an alternative strategy would be to improve local, intracounty roads. The ubiquity of the "distance to nearest economic center" variable in the causal equations of the analysis suggests that Haig's theory also explains land valuation in rural areas. Since the distance to the local economic center is so important in determining land values, a reduction in intracounty transportation costs could greatly enhance rural economic development.

We suggest, therefore, that expenditure emphasis on local roads, rather than arterial highways, may be a superior development policy than a strategy of emphasizing arterial highways alone. Indeed, some notion of "balanced growth" of the entire transportation network should be foremost in the plans of economic development policies.

\section{REFERENCES}

Alonso, William. 1964. Location and Land Use: Toward A General Theory of Land Rent. Cambridge, Mass.: Harvard University Press.

Bowman, Mary Jean and W. Warren Haynes. 1962. The Southern Appalachian Region: A Survey. Lexington, IKentucky: University of Kentucky Press.

Goldberg, Michael A. 1972. "Transportation, Urban Land Values, and Rents: A Synthesis." Land Economics 48 (March): 153-61.

Haig, Robert M. 1927. Major Economic Factors in Metropolitan Growth Arrangement. New York: Regional Plan of New York and Its Environs.

Hale, Carl and Joe Walters. 1974. "Appalachian Regional Development and the Distribution of Highway Benefits." Growth and Change (January): 3-11.

Hansen, Niles M. 1966. "Some Neglected Factors in American Regional Development Policy: The Case of Appalachia." Land Economics 42 (February): 1-9.
Hansen, Niles M. 1970. "How Regional Policy Can Benefit from Economic Theory." Growth and Change (July): 23-28.

Hirschman, Albert. 1958. Strategy of Economic Development. New Haven: Yale University Press.

Kuehn, John and Jerry G. West. 1971. "Highways and Regional Development." Growth and Change (July): 23-28.

Munro, John M. 1969. "Planning the Appalachian Development Highway System: Some Critical Questions." Land Economics 45 (May): 149-161.

Wilson, George, et. al. 1966. The Impact of Highway Investment on Development. Washington, D.C.: The Brookings Institute.

Wingo, Lowden. 1961. Transportation and Urban Land. Washington, D.C.: Resources for the Future.

Wright, Arthur L. and Melvin G. Blase. 1971 "A Depressed Region and Three Myths." Growth and Change (July): 14-22. 